\title{
KAJIAN KUAT TEKAN BETON MUTU TINGGI MEMADAT MANDIRI DENGAN VARIASI BAHAN TAMBAH METAKAOLIN DAN SUPERPLASTICIZER
}

\author{
Wibowo'), Akhmad Fauzi Al Afif'), Supardi ${ }^{3)}$ \\ 1), 3)Staff Pengajar Program Studi Teknik Sipil Fakultas Teknik Universitas Sebelas Maret \\ 2) Mahasiswa Program Studi Teknik Sipil Fakultas Teknik Universitas Sebelas Maret \\ Jl. Ir. Sutami 36 A, Kentingan Surakarta 57126, Telp (0271) 647069, Fax 662118 \\ Email : $\underline{\text { akhmad.fauzi06@gmail.com }}$
}

\begin{abstract}
High strength self-compacting concrete (HSSCC) is concrete wich has high strength that able to self-compact without tool. With metakaolin (MK) as additive then will increase strength quality of the concrete. Research begins with the collection of materials, data connection, aggregate testing, engineering processes, the manufacture of specimens, sample testing, and drawing conclusions. Addition of metakaolin variation as additive of concrete was set at $12.5 \%, 17.5 \%, 22.5 \%$, dan $27.5 \%$ from cement weight, added variation superplasticizer sike viscocrete 1003 as much as 1,5\%,1,7\%, and 1,9\% of the cement weight. Sample made cylinder with dimension $15 \times 30 \mathrm{~cm}$ and 28 days old. This research is expected to know the effect of the addition of metakaolin to the compressive strength of concrete, to know the effect of adding superplasticizer to the compressive strength of concrete, and to know the maximum compressive strength of the variation of metakaolin and superplasticizer. Maximum compressive strength was obtained on percentage of metakaolin $17.5 \%$ and superplasticizer $1.5 \%$ equal to 78.77 $M P a$. The addition of metakaolin reduces the workability of concrete. The addition of metakaolin at 12.5\% and 17.5\% increased the compressive strength of $58.84 \mathrm{MPa}$ and $69.59 \mathrm{MPa}$ (mean of superplasticizer variation), in the $22.5 \%$ and $27.5 \%$ variations decreased by $50.24 \mathrm{MPa}$ and $46.03 \mathrm{Mpa}$. The optimum compressive strength was in the variation of metakaolin $17.02 \%$ by $78.96 \mathrm{MPa}$ with the addition of $1.5 \%$ superplasticizer.
\end{abstract}

Keywords: high strength self-compacting concrete (HSSCC), metakaolin, compressive strength, superplasticizer.

\begin{abstract}
Abstrak
Beton mutu tinggi memadat mandiri memiliki adalah beton dengan kuat tekan tinggi yang dapat memadat mandiri tanpa bantuan alat pemadat. Dengan bahan additive metakaolin (MK) maka akan meningkatkan kualitas kuat tekan beton tersebut. Penelitian dimulai dari pengumpulan material, pengumpulan data, pengujian agregat, proses rekayasa, pembuatan benda uji, pengujian sample, dan mengambil kesimpulan dari penelitian tersebut. Penambahan variasi metakaolin sebagai additive beton ditetapkan 12,5\%, 17,5\%, $22,5 \%$ dan $27,5 \%$ dari berat semen, ditambahkan variasi superplasticizer sika viscocrete 1003 sebanyak $1,5 \%, 1,7 \%$, dan $1,9 \%$ dari berat semen. Bahan uji dibuat silinder dengan dimensi $15 \times 30 \mathrm{~cm}$ berumur 28 hari. Penelitian ini diharapkan dapat mengetahui pengaruh akibat penambahan metakaolin terhadap kuat tekan beton, mengetahui pengaruh penambahan superplasticizer terhadap kuat tekan beton, dan mengetahui kuat tekan maximum dari variasi metakaolin dan superplasticizer. Didapatkan hasil kuat tekan maksimum pada persentase metakaolin 17,5\% dan superplasticizer 1,5\% sebesar 78,77 MPa. Penambahan metakaolin mengurangi workabilitas beton. Penambahan metakaolin pada 12,5\% dan 17,5\% meningkatkan kuat tekan yaitu 58,84 $\mathrm{MPa}$ dan $69,59 \mathrm{MPa}$ (rata-rata dari variasi superplasticizer), pada variasi $22,5 \%$ dan $27,5 \%$ mengalami penurunan yaitu 50,24 MPa dan 46,03 MPa. Kuat tekan optimum berada pada variasi metakaolin 17,02\% sebesar 78,96 MPa dengan penambahan variasi superplasticizer $1,5 \%$.
\end{abstract}

Kata Kunci: beton mutu tinggi memadat mandiri, metakaolin, kuat tekan, superplasticizer.

\section{PENDAHULUAN}

Beton merupakan material konstruksi pokok yang digunakan hingga saat ini di Indonesia. Kelebihan material beton yang mudah dibentuk sesuai dengan bentuk yang diinginkan, kekuatan tinggi dan dapat disesuaikan dengan kebutuhan struktur, tahan terhadap temperature tinggi, mudah didapat bahan bakunya untuk di Indonesia dan memiliki umur yang lama. Beton memiliki kelemahan dalam proses pengerjaannya seperti pada proses pemadatan beton, dalam proses pemadatan diperlukan bantuan getaran dan tumbukan, hal ini menjadi susah ketika pengerjaan beton dilakukan pada daerah-daerah atau tempat yang sempit yang tidak bisa dijangkau oleh vibrator, akibatnya terjadi penurunan kualitas beton. Seiring perkembangan dunia konstruksi maka diciptakanlah beton dengan fluiditas yang tinggi sehingga tidak memerlukan bantuan alat pamadatan beton yaitu Self Compacting Concreate (S.C.C). 
Metakaolin adalah pozolan yang digunakan sebagai bahan pengganti semen untuk meningkatkan kualitas beton HSSCC dan mengurangi kelemahan yang terdapat pada beton konvensional. Metakaolin berasal dari mineral kaolin yang sebelumnya dilakukan kalsinasi pada suhu $650-850^{\circ} \mathrm{C}$ terlebih dahulu, berbentuk serbuk dengan ukuran 0,5 sampai 5 mikron dan berwarna putih. Penggunaan metakaolin di Indonesia masih langka ditemukan, berbeda dengan di negara lain, metakaolin menjadi alternatif geopolimer menggantikan silica fume karena lebih murah dan dapat mencapai kuat tekan serupa silica fume. Dalam penelitian ini, metakaolin diharapkan mampu menambah kuat tekan dan keawetan beton, dan mengurangi porositas dan permeabilitas beton.

Semakin banyak jumlah penambahan metakaolin pada beton, maka workabilitas menurun yang disebabkan oleh luas permukaan metakaolin lebih besar dibandingkan dengan semen. Hal ini dapat diatasi dengan penambahan superplasticizer sehingga parameter SCC beton dapat dijaga. Menurut parameter yang akan dikaji pada penelitian ini adalah kuat tekan dan parameter self compacting concrete. Menurut penelitian lain, penggantian semen dengan metakaolin menurunkan workabilitas beton. Untuk mendapatkan beton dengan bahan tambah metakaolin yang memiliki kuat tekan tinggi dengan workabilitas yang baik, perlu dilakukan penelitian lebih lanjut

\section{DASAR TEORI}

Di beberapa negara maju sudah sejak lama beton mutu tinggi berhasil diproduksi untuk pekerjaanpekerjaan khusus. Pada tahun 1941, di Jepang sudah diproduksi beton mutu tinggi dengan kuat tekan mencapai $60 \mathrm{MPa}$ untuk panel cangkang beton pracetak pada sebuah terowongan kereta api. Pada tahun 1952 di Eropa beton mutu tinggi dengan kuat tekan $60 \mathrm{MPa}$ sudah dipakai untuk struktur jembatan berbentang panjang. Pada tahun 1960, di USA juga sudah diproduksi beton mutu tinggi $60 \mathrm{MPa}$ untuk keperluan militer. Selanjutnya sejak tahun 1980an, beton mutu tinggi dan sangat tinggi banyak digunakan untuk pelaksanaan struktur gedung bertingkat tinggi (terutama untuk elemen kolom). Sejak 1989 sudah digunakan beton bermutu $100-140 \mathrm{MPa}$ untuk jembatan berbentang panjang, bangunan bawah tanah dan lepas pantai, bangunan industri seperti silo yang tinggi dan berdiameter besar, dan juga bangunan beresiko tinggi seperti bangunan reaktor pada pembangkit listrik tenaga nuklir. Di Indonesia beton mutu tinggi dengan kuat tekan rata-rata sebesar $85 \mathrm{MPa}$ baru dapat dibuat di laboratorium pada tahun 1990, dengan bahan tambah superplastisizer dan nilai slump mencapai $15 \mathrm{~cm}$. Campuran beton yang dihasilkan memiliki kadar semen $480 \mathrm{~kg} / \mathrm{cm}$ dan faktor air semen (FAS) 0,32 (Supartono, 1998). Sedangkan realisasi di lapangan maksimal baru mencapai $+80 \%$ nya atau setara dengan $60 \mathrm{MPa}$. (As'ad, 2010).

Dalam dua dekade terakhir, bahan tambah (admixture) pozolan seperti fly ash, silica fume, metakaolin, dan abu sekam telah digunakan sebagai bahan tambah atau pengganti semen karena dapat meningkatkan kekuatan dan ketahanan beton dibandingkan dengan semen portland biasa. Menurut standar ASTM C 618-94a (1993), pozolan ialah bahan yang mempunyai silika atau silika alumina yang memiliki sedikit atau tidak ada sifat semen tetapi apabila dalam bentuk butiran yang halus dan dengan kehadiran kelembaban, bahan ini dapat bereaksi secara kimia dengan $\mathrm{Ca}(\mathrm{OH})_{2}$ pada suhu biasa untuk membentuk senyawa bersifat semen.

Penggunaan superplastisizer atau high range water reducer bertujuan untuk bisa mengontrol dan menghasilkan nilai slump yang optimal pada beton segar (workable), sehingga bisa dihasilkan kinerja pengecoran beton yang baik. Superplastisizer mutlak diperlukan pada beton mutu tinggi atau sangat tinggi, karena kondisi fas yang umumnya sangat rendah. Namun dalam segala hal, penggunaan superplastisizer harus sesuai dengan standar ASTM-C 494-81 tipe F (As'at, 2010)

\section{Metakaolin}

Metakaolin berasal dari kaolin, yaitu sejenis lempung halus berwarna putih yang biasa digunakan sebagai bahan porselen tradisional. Kata awalan "Meta" merupakan istilah yang menunjukkan perubahan. Dalam metakaolin, perubahan yang terjadi adalah dehidroksilasi oleh pemberian panas dalam jangka waktu tertentu. Dehidroksilasi adalah reaksi dekomposisi kristal kaolin menjadi suatu struktur tidak teratur sebagian. Dehidroksilasi terjadi pada pemanasan suhu $420^{\circ} \mathrm{C}$, pada $100-200^{\circ} \mathrm{C}$ kaolin kehilangan sebagian 
besar kandungan air kemudian sisanya melalui dehidroksilasi pada suhu 500 - 800 ${ }^{\circ} \mathrm{C}$ (Patil, 2012). Hasil pengujian kandungan senyawa kimia metakaolin dapat dilihat pada Tabel 1.

Tabel 1 Kandungan Metakaolin

\begin{tabular}{cllllc}
\hline Formula & $\mathbf{Z}$ & Concentration & \multicolumn{1}{c}{ Formula } & $\mathbf{Z}$ & Concentration \\
\hline $\mathrm{SiO} 2$ & 14 & $61,97 \%$ & $\mathrm{La} 2 \mathrm{O} 3$ & 57 & $0,13 \%$ \\
\hline $\mathrm{Al} 2 \mathrm{O} 3$ & 13 & $16,34 \%$ & $\mathrm{MnO}$ & 25 & $0,08 \%$ \\
\hline $\mathrm{NaO} 2$ & 11 & $7,92 \%$ & $\mathrm{SrO}$ & 38 & $0,06 \%$ \\
\hline $\mathrm{CaO}$ & 20 & $4,31 \%$ & $\mathrm{CeO} 2$ & 58 & $0,05 \%$ \\
\hline $\mathrm{Fe} 2 \mathrm{O} 3$ & 26 & $2,01 \%$ & $\mathrm{ZrO} 2$ & 40 & $0,05 \%$ \\
\hline $\mathrm{P} 2 \mathrm{O} 5$ & 15 & $1,58 \%$ & $\mathrm{BaO}$ & 56 & $0,04 \%$ \\
\hline $\mathrm{K} 2 \mathrm{O}$ & 19 & $1,58 \%$ & $\mathrm{SnO} 2$ & 50 & $0,02 \%$ \\
\hline $\mathrm{MgO}$ & 12 & $1,22 \%$ & $\mathrm{~V} 2 \mathrm{O} 5$ & 23 & $0,02 \%$ \\
\hline $\mathrm{SO} 3$ & 16 & $1,14 \%$ & $\mathrm{Ga} 2 \mathrm{O} 3$ & 31 & $0,01 \%$ \\
\hline $\mathrm{Cl}$ & 17 & $1,00 \%$ & $\mathrm{Bi2O} 3$ & 83 & $0,01 \%$ \\
\hline $\mathrm{TiO} 2$ & 22 & $0,36 \%$ & $\mathrm{Nd} 2 \mathrm{O} 3$ & 60 & $0,01 \%$ \\
\hline
\end{tabular}

\section{METODE}

\section{Tinjauan Umum}

Metode yang digunakan dalam penelitian ini adalah eksperimental dengan mencari hubungan antar variabel khususnya pada variasi penambahan metakaolin pada beton high strength self compacting concrete (HSSCC). Variabel penelitian ini terdiri dari variabel bebas dan tidak bebas. Variabel bebas terdiri dari variasi kadar metakaolin, perbandingan penggunaan agregat, faktor air semen dan kadar superplasticizer. Variabel tidak bebas adalah parameter SCC yaitu fillingbility, passingability, segregation resistance, dan kuat tekan.

\section{Benda Uji}

Benda uji yang digunakan adalah beton mutu tinggi memadat mandiri (bigh strength self compacting concrete HSSCC) berbentuk silinder dengan diameter $15 \mathrm{~cm}$ dan tinggi $30 \mathrm{~cm}$. Benda uji dibuat 3 buah per variasi kadar metakaolin yang nantinya akan diambil rata-rata setelah dilakukan uji tekan dengan Compression Testing Machine (CTM).

Tabel 2 Kebutuhan Benda Uji

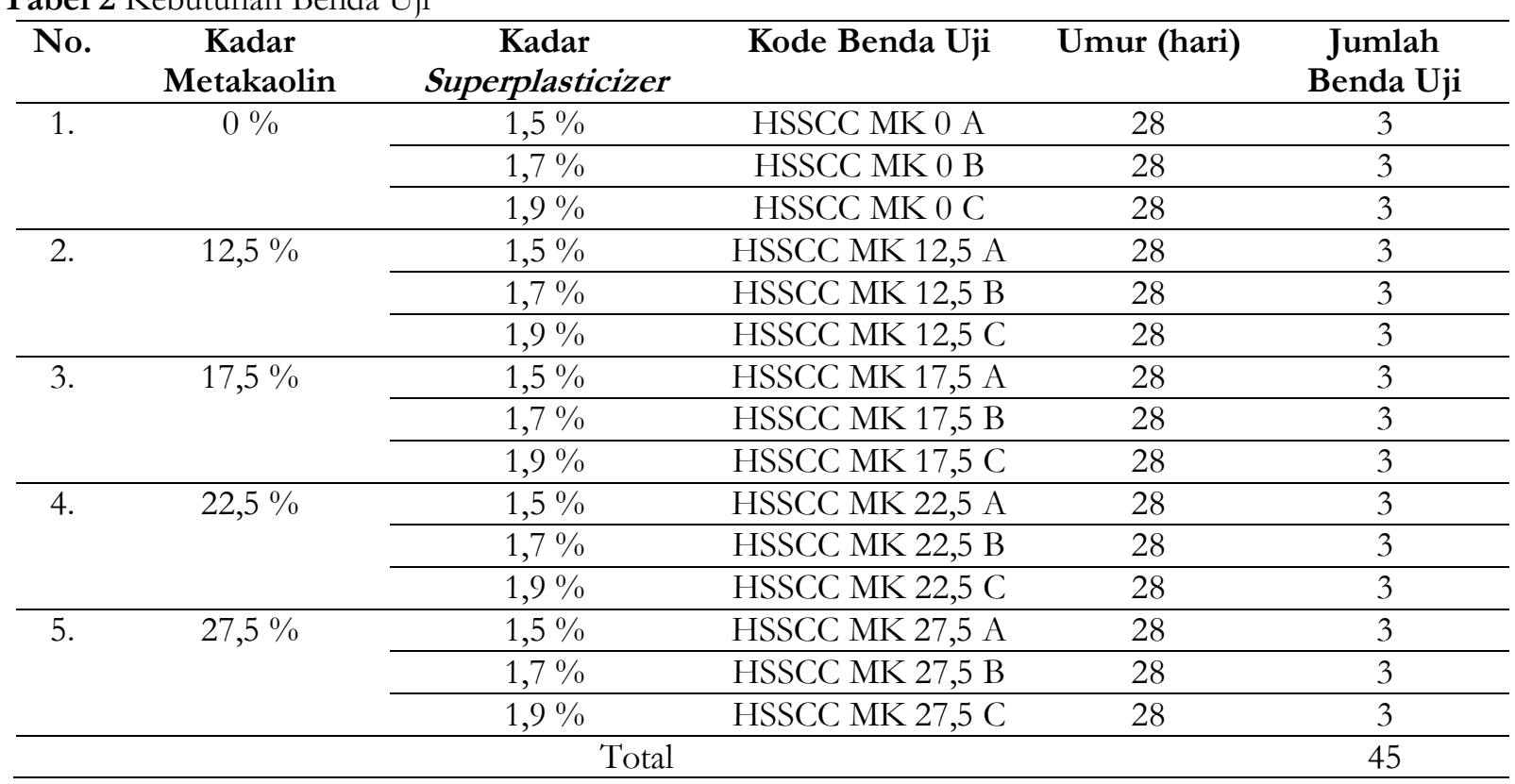


Benda uji sebanyak 45 buah yang nantinya akan di uji dengan menggunakan mesi Compressing Testing Machine (CTM)

\section{Mix Design}

Rancang campur beton mutu tinggi memadat mandiri dengan variasi kadar metakaolin yang digunakan mengacu pada EFNARC 2005. Berdasarkan penelitian sebelumnya, faktor air semen yang digunakan adalah 0,27 dan penggunaan superplasticizer sebanyak 1,7\% terhadap volume air (kadar optimum pada penelitian sebelumnya). Rekapitulasi mix design dapat dilihat pada Tabel 3.

Tabe1 3 Rekapitulasi Mix Design Beton

\begin{tabular}{|c|c|c|c|c|c|c|}
\hline \multirow[t]{2}{*}{ Nama Benda Uji } & \multicolumn{2}{|c|}{ Agregat } & \multicolumn{2}{|c|}{ Sementitius } & \multirow{2}{*}{$\begin{array}{c}\text { Super } \\
\text { plasticizer } \\
\left(1 \mathrm{t} / \mathrm{m}^{3}\right)\end{array}$} & \multirow{2}{*}{$\begin{array}{c}\text { Air } \\
\left(1 \mathrm{t} / \mathrm{m}^{3}\right)\end{array}$} \\
\hline & $\begin{array}{c}\text { Agregat } \\
\text { Halus } \\
\left(\mathrm{kg} / \mathrm{m}^{3}\right)\end{array}$ & $\begin{array}{c}\text { Agregat } \\
\text { Kasar } \\
\left(\mathrm{kg} / \mathrm{m}^{3}\right)\end{array}$ & $\begin{array}{l}\text { Semen } \\
\left(\mathrm{kg} / \mathrm{m}^{3}\right)\end{array}$ & $\begin{array}{c}\text { Metakaolin } \\
\left(\mathrm{kg} / \mathrm{m}^{3}\right)\end{array}$ & & \\
\hline HSSCC MK 0 & 854,14 & 824,07 & 600,00 & 0,00 & 10,20 & 162,00 \\
\hline HSSCC MK12,5 & 849,09 & 828,19 & 525,00 & 75,00 & 10,20 & 162,00 \\
\hline HSSCC MK 17,5 & 846,67 & 825,84 & 495,00 & 105,00 & 10,20 & 162,00 \\
\hline HSSCC MK 22,5 & 844,26 & 823,49 & 465,00 & 135,00 & 10,20 & 162,00 \\
\hline HSSCC MK 27,5 & 841,85 & 821,14 & 435,00 & 165,00 & 10,20 & 162,00 \\
\hline
\end{tabular}

\section{HASIL DAN PEMBAHASAN}

Fillingability

\section{Grafik Waktu Aliran Slump Flow}

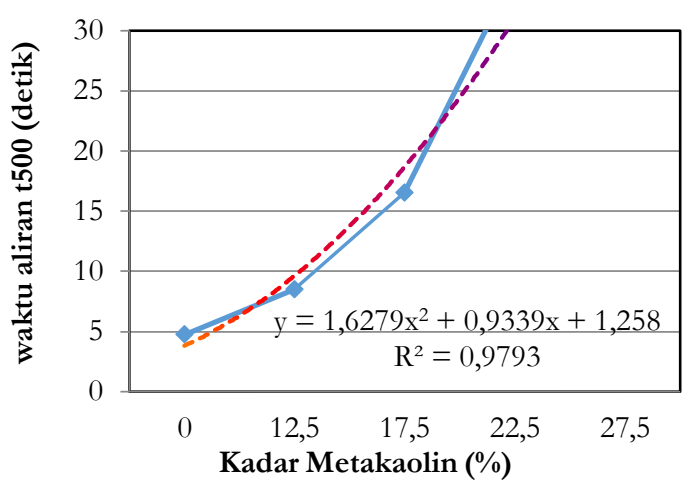

Gambar 1 Grafik Waktu Aliran ( $\left.T_{500}\right)$ Slump Flow

\section{Grafik Diameter Rerata Slump Flow}

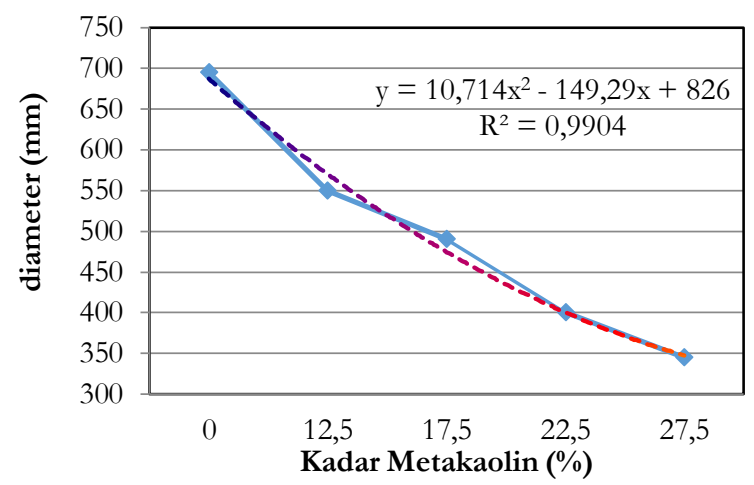

Gambar 2 Grafik Diameter Rerata Slump Flow

Berdasarkan Gambar 1 dan 2 dapat dilihat, semakin tinggi kadar metakaolin yang ditambahkan sebagai pengganti semen maka waktu alir semen semakin lama dan diameter slump rata-rata semakin mengecil dari pada beton acuan. Hal ini disebabkan oleh permukaan metakaolin yang mengikat lebih banyak air sehingga beton menjadi kental. Beton akan mengalami penurunan workabilitas apabila ditambahkan metakaolin, karena sifat metakaolin yang seperti lempung yaitu menyerap air dan memiliki permukaan yang besar disbanding semen. Ukuran metakaolin yang sangat kecil menjadikan permukaan serapnya semakin banyak dan menjadikan luasan serap air semakin besar. 


\section{Passingability}

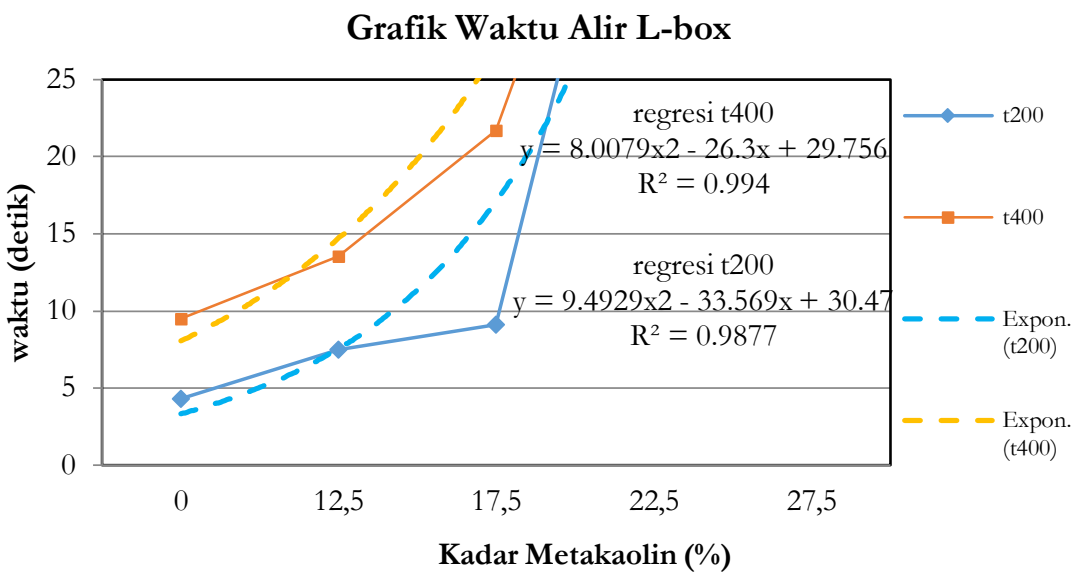

Gambar 3 Grafik Waktu Alir L-box

Gambar 3 menunjukkan bahwa menambahan metakaolin sebagai pengganti semen mengakibatkan air banyak terikat pada butiran metakaolin sehingga beton bersifat kohesif. Passing ratio $\left(\mathrm{h}_{2} / \mathrm{h}_{1}\right)$ menurun seiring bertambahnya kadar metakaolin. Hal ini terbantu oleh penambahan superplasticizer dan retarder yang dapat meningkatkan workabilitas beton segar sehingga menjadikan passingability beton segar dengan bahan additive metakaolin menjadi lebih baik.

\section{Segregation Resistance}
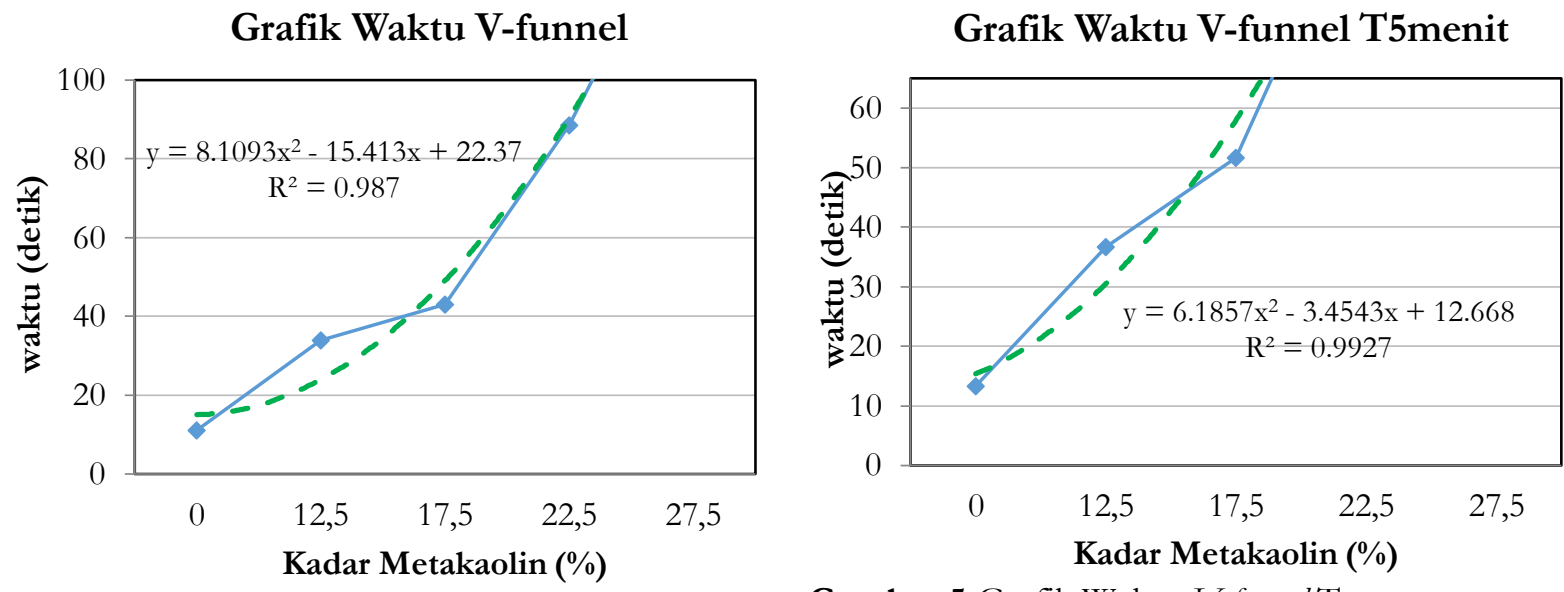

Gambar 4 Grafik Waktu $V$-funnel

Gambar 5 Grafik Waktu $V$-funnel $\mathrm{T}_{5 \text { menit }}$

Berdasarkan Gambar 4 dan 5 Beton segar yang memenuhi persyaratan SCC hanya beton normal tanpa tambahan metakaolin (6-12 detik). Beton yang ditambahkan metakaolin tidak ada yang memenuhi syarat SCC. Penggunaan superplasticizer dan retarder berguna untuk mencegah beton mengeras dan mencegah menggumpal sehingga menambah keenceran beton tetapi tidak segregasi. Waktu alir pada v-funnel menurun daripada beton acuan, dikarenakan penambahan metakaolin sebagai pengganti semen mengakibatkan beton menjadi kental, ukuran butiran metakaolin yang sangat kecil sehingga luas permukaan serap air bertambah lebih besar daripada semen. Sifat metakaolin seperti lempung, yaitu mengikat lebih banyak air sehingga beton menjadi kental. 


\section{Kuat Tekan}

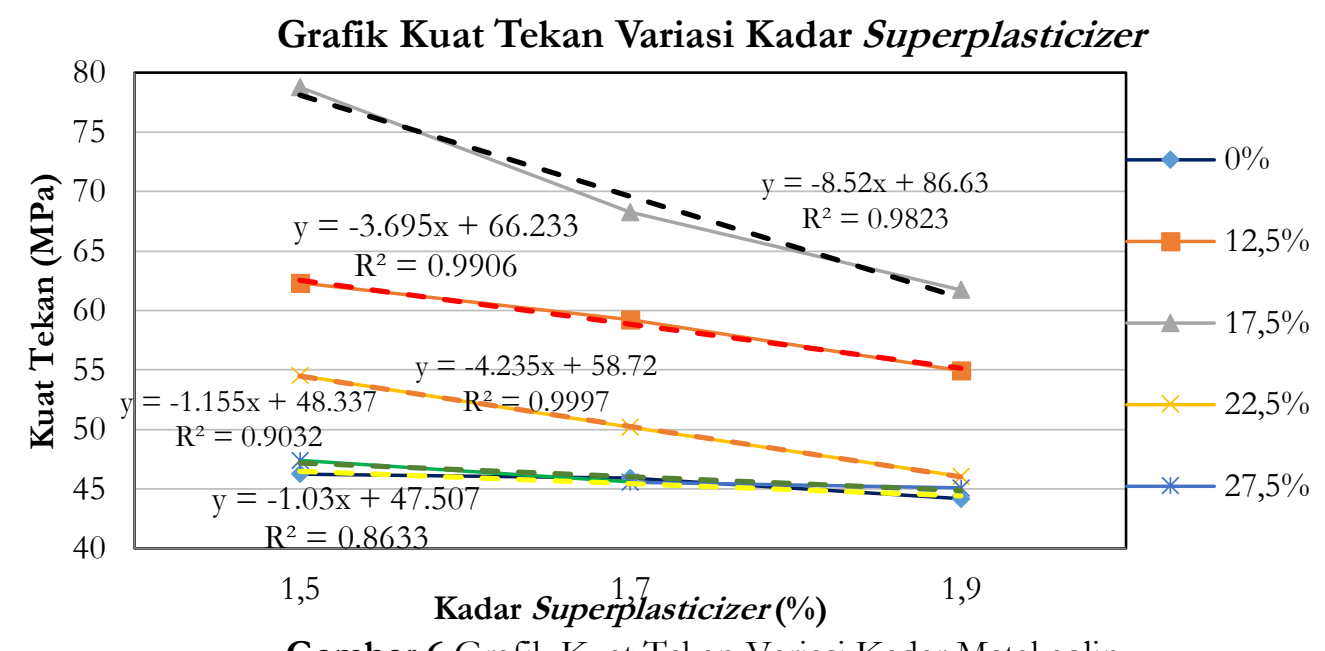

Gambar 6 Grafik Kuat Tekan Variasi Kadar Metakaolin

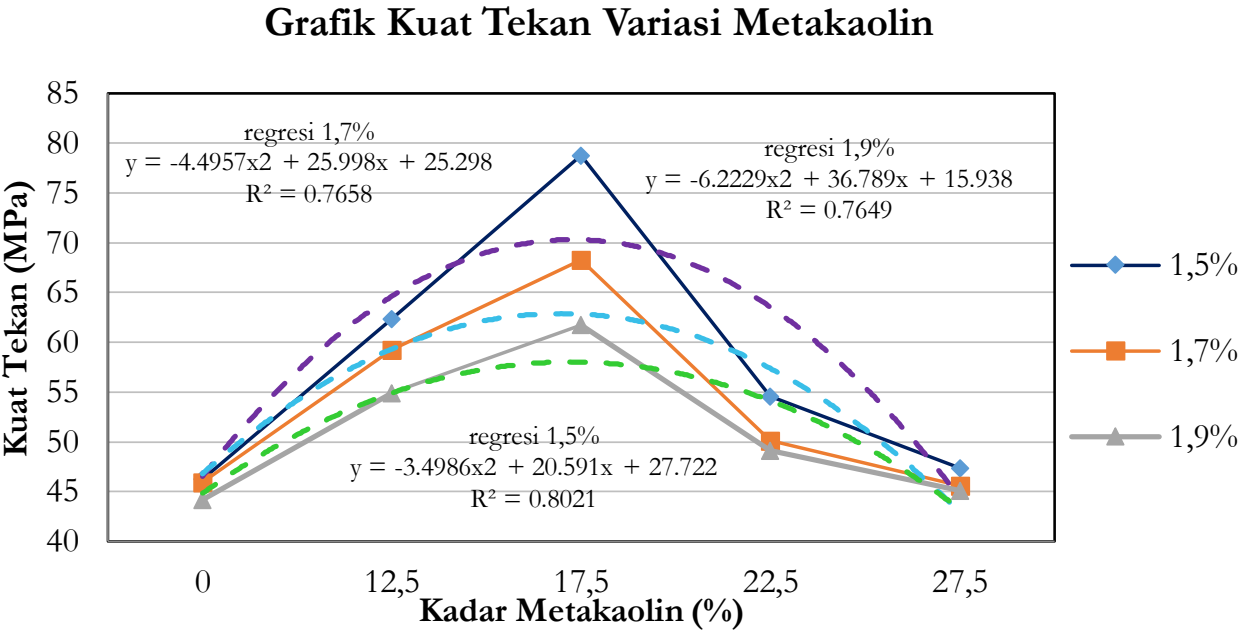

Gambar 7 Grafik Kuat Tekan Variasi Kadar Metakaolin

Gambar 6 dan gambar 7 memperlihatkan variasi penambahan admixture superplasticizer, seiring dengan semakin tingginya superplasticizer yang digunakan pada kadar 1,5\%, 1,7\%, dan 1,9\% kuat tekan semakin menurun. Penambahan superplasticizer akan menambah workability beton segar akan tetapi mengurangi kualitas kuat tekan beton itu sendiri.

Penambahan metakaolin pada dosis tertentu terhadap berat semen akan menambah kuat tekan beton. Senyawa pada semen yang berperan sebagai penguat kuat tekan beton yaitu senyawa $\mathrm{C}_{3} \mathrm{~S}$ dan $\mathrm{C}_{3} \mathrm{~A}$ akan bereaksi dengan senyawa pada metakaolin $\mathrm{SiO}_{2}$ dan $\mathrm{Al}_{2} \mathrm{O}_{3}$. Akan tetapi apabila kadar metakaolin terhadap berat semen terlalu tinggi $(22,5$ - 27,5\%) reaksi pozolanik tidak bekerja secara optimal. Peningkatan kekuatan beton dengan additive metakaolin sesuai dengan penelitian lainnya yang disebabkan oleh reaksi pozolanik metakaolin pada kadar 20\% terhadap berat semen.

Untuk mendapatkan nilai regresi yang optimum, variasi $0 \%$ dan 27,5\% dihilangkan sehingga hanya 12,5\%, $17,5 \%$, dan $22,5 \%$. 


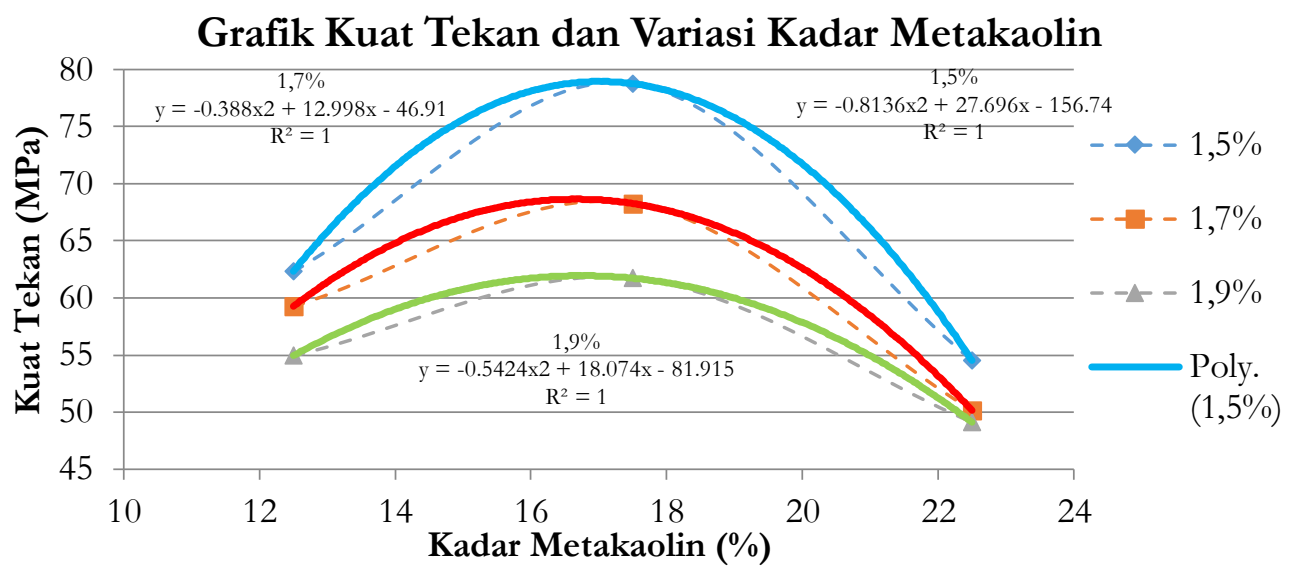

Gambar 8. Grafik Kuat Tekan dan Variasi Kadar Metakaolin

Berdasarkan hasil analisa bahwa garis regresi yang berbentuk adalah garis regresi kurva parabola dapat dilihat pada Gambar 8. di peroleh garis persamaan regresi sebagai berikut :

Kuat tekan saat beton hancur

$Y=-0,8136 x^{2}+27,696 x-156,74$

uji hipotesis ini berfungsi untuk mengetahui persentase penambahan metakaolin optimal dalam beton umur 28 hari terhadap kuat tekan, dengan mendefinisikan persamaan regresi garis lengkung $\mathrm{y}=\mathrm{a} \mathrm{x}^{2}+\mathrm{bx}$ + c sehingga didapat $\frac{d y}{d x}=0$.

$Y=-0,8136 x^{2}+27,696 x-156,74$

Dideferensialkan sehingga didapat :

$\frac{d y}{d x}=0$

$2(-0,8136) x+27,696=0$

$1,6272 x+27,696=0$

$x=\frac{-27,696}{-1,6272}=17,02 \%$

Untuk mencari harga $\mathrm{Y}$, maka $\mathrm{x}$ di distribusikan ke persamaan kurva sebagai berikut :

$y=-0,8136 x^{2}+27,696 x-156,74$

$y=-0,8136(17,02)^{2}+27,696(17,02)-156,74$

$y=78,96 \mathrm{MPa}$

Berdasarkan perhitungan dapat ditarik suatu kesimpulan bahwa prosentas komposisi metakaolin terhadap kuat tekan beton yang optimall dicapai pada komposisi 17,02\% dengan kuat tekan beton optimum sebesar $78,96 \mathrm{MPa}$ dengan penambahan variasi superplasticizer 1,5\%. Pada kadar 22,5\% terhadap berat pengikat mengalami penurunan, dikarenakan ikatan pozolanik senyawa $\mathrm{SiO}_{2}$ pada metakaolin dan $\mathrm{CA}(\mathrm{OH})_{2}$ yang merupakan sisa dari hidrasi semen tidak bereaksi secara maskimal seperti yang telah diteliti oleh Ade Ilham (2005). Kandungan $\mathrm{SiO}_{2}$ yang tinggi, kandungan karbon yang rendah, luas permukaan yang besar dan ukuran butiran yang halus menjadikan metakaolin membantu peningkatan kuat tekan yang signifikan. Reaksi kimia dapat dilihat pada Gambar 9.

$\mathrm{MK}\left[\mathrm{Al}_{2} \mathrm{Si}_{2} \mathrm{O}_{7}\right]+\mathrm{CH}+\mathrm{H} \rightarrow \mathrm{C}-\mathrm{S}-\mathrm{H}, \mathrm{C}_{4} \mathrm{AH}_{13}, \mathrm{C}_{3} \mathrm{AH}_{6}, \mathrm{C}_{2} \mathrm{ASH}_{3}$ 


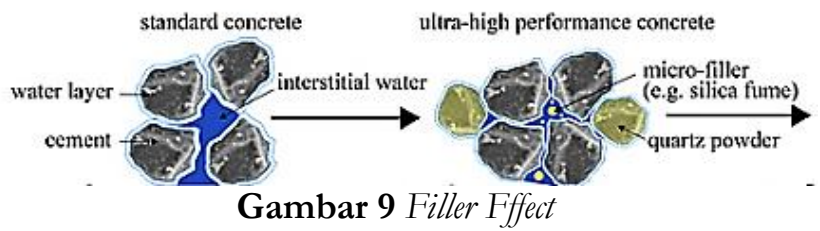

Rheology dapat diartikan sebagai ilmu yang mempelajari mengenai pergerakan materialbaik dari zat cair dan deformasi zat padat. Rheology pada beton biasanya ditentukan dengan melihat dua parameter yaitu yield stress dan viskositas. Campuran beton segar yang ditambah superplasticizer akan menurunkan yield stress dan viscositas seiring bertambahnya dosis superplasticizer. Hal ini karena superplasticizer memiliki muatan negatif dan bila bercampur dengan air dan semen maka akan menghasilkan gaya tolak menolak (dispersion) sehingga flowability campuran meningkat. Penambahan metakaolin pada beton segar akan meningkatkan yield stress dan viskositas yang mengakibatkan beton menjadi lekat (kental) sehingga menurunkan flowability. Akan tetapi dapat menjadi material anti-segregasi karena metakaolin mempunyai ukuran yang halus dan permukaan serap yang tinggi sehingga mengikat banyak air.

\section{SIMPULAN}

Dari data hasil pengujian, analisis data, dan pembahasan beton mutu tinggi memadat mandiri dengan variasi bahan tambah metakaolin dan superplasticizer. dapat ditarik kesimpulan sebagai berikut:

1. Penambahan variasi kadar metakaolin terhadap berat semen meningkatkan kuat tekan beton. Peningkatan terjadi pada penambahan kadar metakaolin sebesar $12,5 \%$ dan $17,5 \%$ berturut-turut sebesar 58,84 MPa dan 69,59 MPa. Pada kadar metakaolin 22,5\% dan 27,5\% mengalami penurunan berturut-turut yaitu 50,24 MPa dan 46,03 MPa

2. Pengaruh penambahan admixture superplasticizer terhadap kuat tekan beton mutu tinggi memadat mandiri (HSSCC) yaitu, semakin besar kadar superplasticizer yang diberikan maka semakin menurunkan kekuatan tekan beton.

3. Kuat tekan beton optimum yang dapat dicapai sebesar 70,07 MPa dengan variasi kadar metakaolin $17,07 \%$ dan kadar superplasticizer $1,5 \%$.

\section{REKOMENDASI}

1. Perlu penelitian lebih lanjut pada penggunaan kadar metakaolin antara $17,5 \%$ sampai $22,5 \%$ dan mempertimbangkan kembali kadar air dan kadar superplasticizer untuk mencapai parameter self compacting concrete.

2. Penambahan bahan uji diperlukan agar data pengujian lebih valid dan menjadi cadangan apabila ada sampel yang rusak (tidak sesuai)

3. Untuk mendapatkan hasil yang lebih baik lagi maka dapat diadakan penelitian tentang pengaruh gradasi agregat kasar dan halus terhadap kuat tekan beton.

4. Untuk mendapatkan hasil yang lebih baik lagi maka dapat diadakan penelitian perbandingan kuat tekan pada umur 3, 7, 14, 21 hari, bahkan jika waktunya memungkinkan dapat diadakan sampai dengan umur 90 hari.

5. Pastikan pengerjaan pembuatan beton dilakukan dengan metode yang benar dan pengujian beton segar dilakukan sesegera mungkin agar didapatkan hasil yang maksimal.

\section{UCAPAN TERIMAKASIH}

Ucapan terima kasih pertama ditujukan kepada Allah SWT atas limpahan rahmat dan nikmatnya. Selanjutnya kepada Wibowo S.T., DEA dan Ir. Supardi M.T. selaku dosen pembimbing yang telah memberi arahan dan masukan dalam penelitian ini.

\section{REFERENSI}

As'ad, Solihin. 2012. "Beton Memadat Mandiri”. Harian JOGLOSEMAR, 12 Agustus 2012.

Dharmawan, E.A., Wibowo, dan Mediyanto, A., 2017. "Kajian Pengarub Variasi Kompposisi Metakaolin Terbadap Parameter Beton Memadat Mandiri dan Kuat Tekan Beton Mutu Tinggi". Skripsi, Program Studi Teknik Sipil Fakultas Teknik Universitas Sebelas Maret. 
Herbudiman, B., Siregar, S.E. 2013. "Kajian Interval Rasio Air-Powder Beton Self-Compacting Terkait Kinerja Kekuatan dan Flow". Jurusan Teknik Sipil Institut Teknologi Nasional (Itenas) Bandung.

lham Ade, 2005. "Pengaruh Sifat-sifat Fisik dan Kimia Bahan Pozolanik pada Beton Kinerja Tinggi". Penelitian, Jurusan Teknik Sipil, Universitas Islam Indonesia, Yogyakarta.

Istianto, M.M. 2010. "Kajian Kuat Desak dan Modulus Elastisitas Beton dengan Baban Tambah Metakaolin dan Serat Aluminium”. Skripsi, Jurusan Teknik Sipil Fakultas Teknik Universitas Sebelas Maret Surakarta.

Pujianto, A., Retno, T., dan Ariska, O. 2010. "Beton Mutu Tinggi Dengan Admixture Superplastiziser dan Aditif Silicafume”. Jurusan Teknik Sipil Fakultas Teknik Universitas Muhammadiyah Yogyakarta.

Rusyandi, K., Mukodas, J. \& Gunawan, Y. 2012. "Perancangan Beton Self Compacting Concrete" Penelitian, Sekolah Tinggi Teknologi Garut,

Soetjipto \& Ismoyo. 1978. "Kontruksi Beton 1”. Jakarta : Dikdasmen

Srivastava, V., Kumar, R., Agarwal, V.C.. 2012 "Metakaolin Inclusion: Effect on Mechanical Properties of Concrete". Civil engineering department MNNIT, Allahabad, India.

Supartono, F.X. 1998. "Beton Berkinerja Tinggi dan Keterikatannya dengan Pembangunan Nasional Memasuki Abad 21". Penelitian, Jurusan Teknik Sipil Fakultas Teknik Universitas Indonesia.

Tjokrodimulyo, Kardiyono. 1995. “Teknologi Beton”. Yogyakarta: Biro Penerbit Teknik Sipil Universitas Gajah Mada. 